УДК 582.382.22:581.4

\title{
Spore morphology of Selaginella borealis, S. sanguinolenta and S. helvetica (Selaginellaceae, Lycopodiophyta)
}

\author{
A. V. Vaganov ${ }^{1,3}$, A. P. Shalimov ${ }^{2}$, A. A. Kechaykin ${ }^{1}$, M. V. Skaptsov ${ }^{1}$, S. V. Smirnov ${ }^{1}$, T. A. Sinitsyna ${ }^{1}$ \\ M. G. Kutsev' ${ }^{1}$ X.-C. Zhang ${ }^{2}$, A. I. Shmakov ${ }^{1}$ \\ ${ }^{1}$ South-Siberian Botanical Garden, Altai State University, pr. Lenina, 61, Barnaul, 656049, Russian Federation. \\ E-mail:vaganov_vav@mail.ru* \\ ${ }^{2}$ State Key Laboratory of Systematic and Evolutionary Botany, Institute of Botany, Chinese Academy of Sciences, Beijing, \\ China, № 20 Nanxincun, Xiangshan.E-mails: shalimov_ap@ibcas.cn, zhangxc@ibcas.ac.cn \\ ${ }^{3}$ Sakhalin Branch of the Botanical Garden-Institute FEB RAS, A. M. Gorkogo str., 25, Yuzhno-Sakhalinsk, 693023, \\ Russian Federation
}

Keywords: Lycopodiophyta, microspores, megaspores, Russia, scanning electronic microscopy (SEM), Selaginella, Selaginella borealis, Selaginella sanguinolenta, Selaginella helvetica, Selaginellaceae, Siberia, spore morphology.

Summary. For the first time we have conducted a study of three species of the genus Selaginella P. Beauv. from Russia: S. sanguinolenta (L.) Spring, S. helvetica (L.) Link and S. borealis (Kaulf.) Rupr. using the method of scanning electron microscopy (SEM). In a comparative analysis of the morphology of micro- and megaspores of S. sanguinolenta, $S$. helvetica and $S$. borealis, we first compiled an information on representatives of Selaginella from the territories of China and Russia. A distinctive feature of S. borealis and S. sanguinolenta based on the megaspore morphology is the different nature of the exosporium surface: $S$. borealis has the exosporium with rounded-polygonal tubercles, and $S$. sanguinolenta has the exosporium with roller-like folds rising above the sporoderma. S. sanguinolenta is characterized by following species-specific features of microspores: the presence of radially arranged convolutions on the proximal surface of the spore, outside the laesura, and convoluted folds on the distal surface of the microspores. $S$. helvetica is characterized by the following microspore morphology: the hemispherical distal side is in the equatorial position, and flat proximal side; the surface of the exosporium is granular, completely covered with rounded-polygonal tubercles. In the research we confirmed the presence of S. borealis in China (Yunnan). It has been established that the morphology of S. sanguinolenta microspores from the Khabarovsk Territory, the Republics of Buryatia, Tuva and the Irkutsk Region is identical to the microspores of representatives of S. sanguinolenta from China (Yunnan); and the morphology of S. helvetica microspores from the territory of the Chita Region, Trans-Baikal and Primorye Territories is identical to the morphology of the species samples from Liaoning Province (China).

\section{Морфология спор Selaginella borealis, S. sanguinolenta и S. helvetica (Selaginellaceae, Lycopodiophyta)}

\author{
А. В. Ваганов ${ }^{1,3}$, А. П. Шалимов ${ }^{2}$, А. А. Кечайкин ${ }^{1}$, М. В. Скапцов ${ }^{1}$, С. В. Смирнов ${ }^{1}$, Т. А. \\ Синицына ${ }^{1}$, М. Г. Куцев ${ }^{1}$, С.-Ч. Жан ${ }^{2}$, А. И. Шмаков ${ }^{1}$ \\ ${ }^{1}$ Южно-Сибирский ботанический сад, Алтайский государственный университет, \\ пр. Ленина, 61, г. Барнаул, 656049, Россия \\ 2 Лаборатория систематики и эволюичонной ботаники, Институт ботаники \\ Китайской академии наук, г. Пекин, Китай \\ ${ }^{3}$ Сахалинский филиал Ботанического сада-института ДВО РАН, ул. А. М. Горького, 25, \\ 2. Южно-Сахалинск, 693023, Сахалинская область, Россия
}


Ключевые слова: мегаспоры, микроспоры, морфология спор, Россия, сканирующая электронная микроскопия (СЭМ), Сибирь, Lycopodiophyta, Selaginella, Selaginella borealis, Selaginella sanguinolenta, Selaginella helvetica, Selaginellaceae.

Аннотация. Методом сканирующей электронной микроскопии (СЭМ) впервые проведено исследование трех представителей рода Selaginella Р. Beauv. с территории России: S. sanguinolenta (L.) Spring, S. helvetica (L.) Link и $S$. borealis (Kaulf.) Rupr. В ходе сравнительного исследования морфологии микро- и мегаспор $S$. sanguinolenta, S. helvetica и S. borealis нами впервые были обобщены сведения по представителям Selaginella с территории Китая и России. Отличительной чертой видов S. borealis и S. sanguinolenta, основанной на особенностях морфологии мегаспор, является различный характер поверхности экзоспория: у S. borealis - экзоспорий с бугорками округло-многоугольной формы, у S. sanguinolenta - экзоспорий с валиковидными складками, поднимающимися над спородермой. Видоспецифичными признаками микроспор, характеризующими S. sanguinolenta являются: наличие на проксимальной поверхности споры, вне лезур, радиально расположенных извилин, а также извилистых складок на дистальной поверхности микроспор. Признаками морфологии микроспор, характеризующими представителей $S$. helvetica, являются: полусферическая дистальная сторона в экваториальном положении, а проксимальная - плоская; поверхность экзоспория зернистая, полностью покрытая округло-многоугольными бугорками. В ходе проведенного исследования нами подтверждено наличие S. borealis на территории Китая (Юньнань). Установлено, что морфология микроспор S. sanguinolenta с территории Хабаровского края, Республик Бурятия, Тыва и Иркутской области идентичны микроспорам представителей S. sanguinolenta с Китая (Юньнань), а морфология микроспор образцов $S$. helvetica с территории Читинской области, Забайкальского и Приморского краев идентичны морфологии образцов, исследованных с провинции Ляонин (Китай).

\section{Introduction}

Genus Selaginella P. Beauv. (Selaginellaceae) is the largest family in the Lycopodiophyta (Zhou, Zhang, 2015). Representatives of Selaginellaceae are distributed almost worldwide, mainly in the tropics (Tryon, Lugardon, 1991, Zhou et al., 2015b). Representatives of the genus prefer not only the main habitats of the temperate, subtropical and tropical zones, including the desert, but also enter arctic areas and climb the mountains in the alpine belt (Jermy, 1990; Zhang et al., 2013; Zhou, Zhang, 2015).

In the territory of Russia, the genus is represented by 8 species (Tzvelev, 2004), of which the complex Selaginella borealis-S. sanguinolenta is most difficult. Many researchers recognize both these species as independent (Tzvelev, 2004), and some consider them as one polymorphic species (Zhang et al., 2013).

The spore morphology of Selaginella representatives is important in the systematics of the genus. Using the spore morphology researchers differentiate some taxonomic and complex species (Zhou et al., 2015a). Such conclusions were made by Zhou's research team based on 70 Selaginella species from China. Using the morphological characteristics of megaspores and/or microspores, the researchers divided the spores of the Chinese representatives of the genus into 15 types, and three more types were divided into different subtypes. Wherein some types reflect the species composition of the clades and subclades identified in further molecular genetic studies of Zhou et al. (2015b).

According to Japan samples the megaspore morphology of $S$. helvetica refers to seventh spore type"The Selaginella pallidissima type" (species composition of the type: S. pallidissima, S. denticulata, $S$. helvetica, S. jugorum, S. laxistrobila, S. nipponica, S pallidissima, S. prostrata, S. pseudonipponica, S. rubella, S. tama-montana) (Zhou et al., 2015a). Megaspores of this type are characterized by a rounded or almost rounded shape, the presence of a wide laesura, occupying a length of $1 / 2-3 / 4$ the size of the equatorial diameter on the proximal side. The proximal surface of the megaspore is warty, and the distal surface is covered with furrows with a curved ornament.

Similar characteristics on the $S$. helvetica megaspores are given by researchers on samples from Europe and North Asia (without specifying the herbarium samples from the Herbarium "S" of the Swedish Museum of Natural History). At the same time, there is an additional clarification in terms of the sizes of $S$. helvetica megaspores - 350-400 $\mu \mathrm{m}$ in the morphological description (Korall, Taylor, 2006).

$S$. helvetica spores on samples from China (Liaoning province) are characterized by the presence of a hemispherical microspore. The microspore laesura occupies $3 / 4$ the size of the equatorial diameter on the proximal side. The proximal and distal surfaces of microspores are warty, sometimes with ridges (Zhou et al., 2015a). 
Zhou et al. (2015a) used S. sanguinolenta specimens (including specimens of $S$. borealis, without a species separation of these two taxa) from Yunnan Province to study the morphology of spores. According to this study the megaspore morphology of $S$. sanguinolenta is related to the first spore type "The Selaginella sanguinolenta type" (species composition of the type: S. nummularifolia, S. rossii, $S$. sanguinolenta). Megaspores of this type have a tetrahedral form; a laesura occupies a length of $3 / 4$ the size of an equatorial diameter. The proximal and distal surfaces of megaspores are warty. The microspore form of $S$. sanguinolenta is also tetrahedral, as megaspore one. Laesuras are clearly defined and reach the equator in length. The proximal and distal microspore surfaces are wrinkled (Zhou et al., 2015a).

We should note, that Zhou et al. have proposed generalized morphological spore types features which characterize the group of species studied. This creates difficulties in identifying certain species using the characters of the spore morphology, that is especially important in species differentiation in such complex taxa as $S$. borealis and $S$. sanguinolenta. In this study, the task was to identify the speciesspecific features of the megaspore morphology of $S$. borealis and $S$. sanguinolenta representatives, as well as to clarify the information on the morphology of $S$. sanguinolenta and $S$. helvetica microspores.

\section{Material and methods}

A material for the study was the spore samples from the herbarium material of the Central Siberian Botanical Garden of the Siberian Branch of the Russian Academy of Sciences (NS), G. G. Popov Herbarium of the Central Siberian Botanical Garden of the SB RAS (NSK), Irkutsk State University (IRKU), Siberian Institute of Plant Physiology and Biochemistry SB RAS (IRK). In total, we selected 10 samples for the study on 3 species of the genus Selaginella, from the territory of Republics of Tuva and Buryatia, Irkutsk and Chita Regions, Khabarovsk and Primorye Territories. The spore studies were conducted in the laboratory of the Institute for Water and Environmental Problems (IHEP SB RAS, Barnaul), using a Hitachi S 3400 $\mathrm{N}$ electronic scanning microscope from Hitachi High-Technologies Corp. Spores were applied on double sided tape, fastened on metal object tables with a diameter of $10 \mathrm{~mm}$. The spore surface was treated with a gold-palladium mixture in an Emitech SC 7620/QT S vacuum evaporation unit for about 6 minutes.
All spore samples were examined under high vacuum. The studied samples were scanned with an increase from $\times 400$ (general view of the spores) to $\times 14000$ (study of the surface of exosporium).

The analysis of spores was carried out according to the following morphological features, $\mu \mathrm{m}: 1-$ equatorial diameter; 2 - the polar axis; 3 - laesura length; 4 - laesura width; 5 - diameter of the tubercles on the proximal side of the spore; 6 - diameter of the tubercles on the dorsal side of the spore; 7 diameter of the tubercles on the proximal side of the spore near the laesuras; 8 - the width of the curved folds on the distal side; 9 - the width of the convolutions on the proximal side. The measurements were carried out in a 20 -fold repetition.

\section{Results and discussion}

\section{Morphological descriptions of micro- and megaspores of the Selaginella species.}

\section{Selaginella sanguinolenta (L.) Spring}

SEM description (Fig. 1.). The spores in the proximal-polar and distal-polar positions are rounded-triangular, not lobed. The equatorial diameter is 46.76 (from 32.8 to 64.3 ) $\mu \mathrm{m}$. The polar axis is 26.3 (from 25.4 to 27.3 ) $\mu \mathrm{m}$. In the equatorial position, the distal side is hemispherical, proximal - conical. Laesura arms are straight, 15.72 (from 13.4 to 17.0) $\mu \mathrm{m}$ long, 2.27 (from 1.8 to 2.9 ) $\mu \mathrm{m}$ wide. The surface on the proximal side of the spores out of the laesuras is flat, or with the presence of convolutions radially located from the edges of the laesuras, 1.3 (0.8 to 2.2) $\mu \mathrm{m}$ wide. There are convoluted folds, 3.74 (from 1.8 to 7.1 ) $\mu \mathrm{m}$ wide, across the distal surface of the spore. The surface of the exosporium is rough, without outgrowths.

Specimens examined: "Khabarovskiy territory, Ayano-Mayskiy district, vicinity of village Aym, left rocky bank of river Maya, Pinus sylvestris forest, almost continuous cover on the rocks, abundant. Leg. S. Kharkevich, T. Buch. Det. S. Kharkevich. 21 VI 1978" (IRK); "Buryatia, Eravninsky District, state farm "Tuldunsky", rocky slope. 23 VII 1989. No. 0172. Coll. T. Ivantsova. Det. A. Zarubin" (IRKU); "Irkutsk Region, Slyudyansky District, st. Maritui, $121 \mathrm{~km}$. On the rock at the foothill. 27 VI 1989. No. 0160. Kacherova" (IRKU); "Tuvinskaya ASSR, Tandinsky District, East Tannu-Ola, near Lake Chagytai. $51^{\circ} 00^{\prime} \mathrm{N}, 94^{\circ} 50^{`} \mathrm{E}$. Starched steppe. 29 VII 1983. No. 28. I. M. Krasnoborov. NS0004571" (NS); "Tuvinskaya ASSR, Kaa-Khem District, near collective farm Derzig, $15 \mathrm{~km}$ from the mouth of the Derzig river, $\mathrm{H}=800 \mathrm{~m}$. Granite overlooks on a 

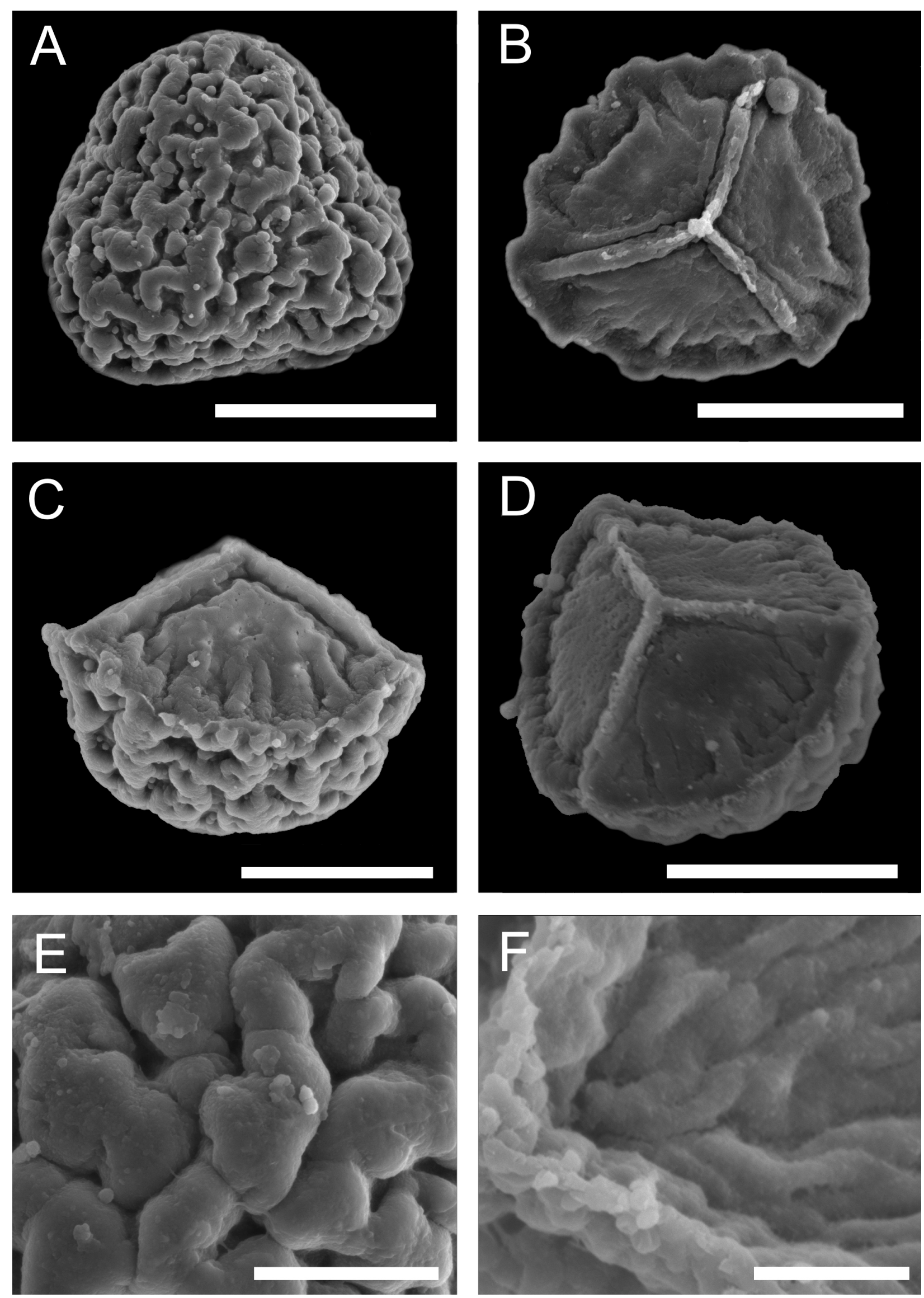

Fig. 1. SEM- photographs of microspores of Selaginella sanguinolenta: A - the distal side of the spore; B - proximal side of the spore; $\mathrm{C}$ - the spore in equatorial position; $\mathrm{D}$ - the spore in equatorial-proximal position; $\mathrm{E}$ - distal spore surface; F - proximal spore surface with laesura. The scale bar is $30 \mu \mathrm{m}(\mathrm{A}), 20 \mu \mathrm{m}(\mathrm{B}-\mathrm{D}), 10 \mu \mathrm{m}$ (E) and $5 \mu \mathrm{m}(\mathrm{F})$. 

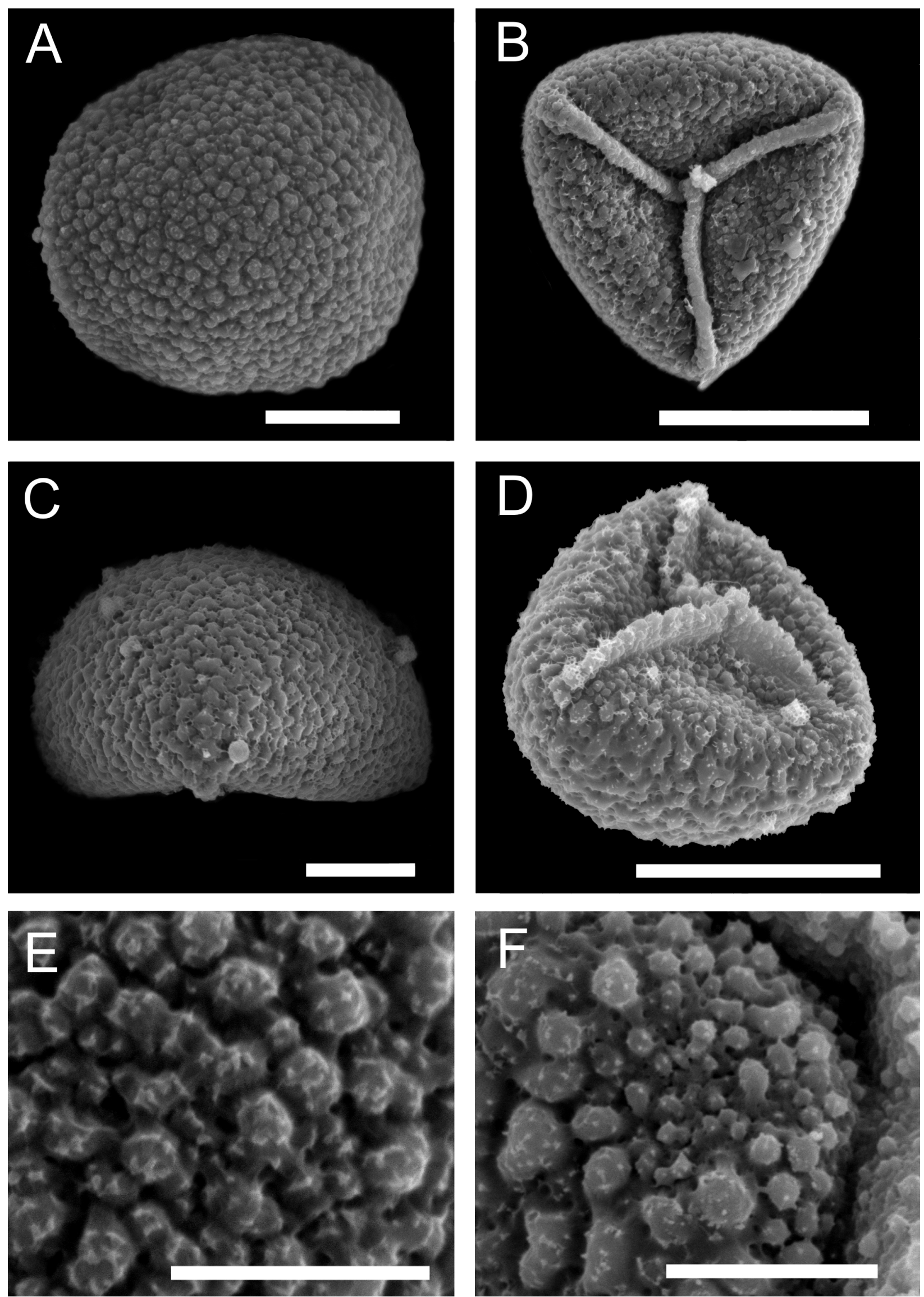

Fig. 2. SEM photographs of microspores of Selaginella helvetica: A - the distal side of the spore; B - the proximal side of the spore; $\mathrm{C}$ - the spore in equatorial position; $\mathrm{D}$ - the spore in equatorial-proximal position; $\mathrm{E}$ - the distal spore surface; F - proximal spore surface with a laesura. Scale bar of $20 \mu \mathrm{m}(\mathrm{B}, \mathrm{D}), 10 \mu \mathrm{m}(\mathrm{A}, \mathrm{C})$ and $5 \mu \mathrm{m}(\mathrm{E}, \mathrm{F})$. 
steep eastern slope. 22 VII 1974, No. 333. I. Krasnoborov, V. Khanminchun. NS0003983” (NS).

\section{Selaginella helvetica (L.) Link}

SEM description (Fig. 2.). Spores in the proximal-polar position are rounded-triangular, not lobed; round in the distal-polar position. The equatorial diameter is 29.78 (from 27.5 to 32.0 ) $\mu \mathrm{m}$. The polar axis is 23.43 (from 22.1 to 24.5 ) $\mu \mathrm{m}$. In the equatorial position, the distal side is hemispherical, proximal - flat. The laesura arms are straight, 15.97 (from 15.0 to 17.1 ) $\mu \mathrm{m}$ long, 1.33 (from 1.0 to 1.6$) \mu \mathrm{m}$ wide, rising above the sporoderm surface, clearly expressed or immersed in it. Exosporium torulose. Tubercles are rounded-polygonal, 0.9 (from 0.6 to 1.2 ) $\mu \mathrm{m}$ in diameter, up to $0.2-0.4 \mu \mathrm{m}$ in diameter near laesuras. The surface of exosporium is granular.

Specimens examined: "Trans-Baikal Territory, Mogochinsky District, r. Shilka, left bank, Chasovinka village, $\mathrm{H}=345 \mathrm{~m}$. Point $352.53^{\circ} 29^{\prime} 21^{\prime \prime} \mathrm{N}$, $120^{\circ} 02^{`} 51^{\prime \prime} \mathrm{E}$. The forested (larch, birch) rocky slope of the north-eastern exposure. Field number: 1627. 12 VII 2011. No. 19520. Coll. S. G. Kazanovsky, O. D. Chernova. Det. S. G. Kazanovsky" (IRK); "Primorskiy territory, Krasnoarmeyskiy district, vicinity of village Roschyno, dry plumb rocks along road, continuous cover. Leg. S. Kharkevich, I. Vyshin. Det. S. Kharkevich. 25 VII1984" (IRK); "Eastern Transbaikalia, r. Shilka, rocks to the valley of the Kurengi river, near the town of Sretensk, northern slope. 14 VIII 1963. G. Peshkova" (NSK);
"Chita Region, vicinity of city of Nerchinsk, r. Nercha at the confluence of the river Shilka. Rocky slope to r. Nercha, raw, semi-enriched. 12 VII 1989. No. 1559. Coll. A. Bardunov. Det. A. Kiseleva” (IRK).

\section{Selaginella sanguinolenta (L.) Spring}

SEM description (Fig. 3.). The spores in proximal-polar and distal-polar positions are rounded. The equatorial diameter is 303.0 (from 297 to 312) $\mu \mathrm{m}$. The exosporium is covered with roller-like folds, rising above the sporoderm, reaching a width of 8.3 (from 5.8 to 12.2 ) $\mu \mathrm{m}$. The distance between adjacent roller-like folds reaches the width of the folds themselves. The surface of the exosporium is rough.

Specimen examined: "Tuvinskaya ASSR, Tandinsky District, East Tannu-Ola, in env. Lake Chagytai. $51^{\circ} 00^{\prime} \mathrm{N}, 94^{\circ} 50^{`} \mathrm{E}$. Starched steppe. $29 \mathrm{VII}$ 1983. No. 28. I. M. Krasnoborov. NS0004571" (NS).

\section{Selaginella borealis (Kaulf.) Rupr.}

SEM description (Fig. 4.). The spores in the proximal-polar and distal-polar positions are tetrahedral to rounded. Equatorial diameter is 296.2 (from 274 to 309) $\mu \mathrm{m}$. The polar axis is 243.7 (from 237 to 253$) \mu \mathrm{m}$. In the equatorial position, the distal side of the spore is hemispherical, proximal - conical. The laesura arms are straight, 123.0 (from 112 to 130.0 ) $\mu \mathrm{m}$ long, 13.24 (from 9.2 to 18.00 ) $\mu \mathrm{m}$ wide, rising above the sporoderm. Exosporium is nodular. The tubercles are rounded-polygonal, 4.9
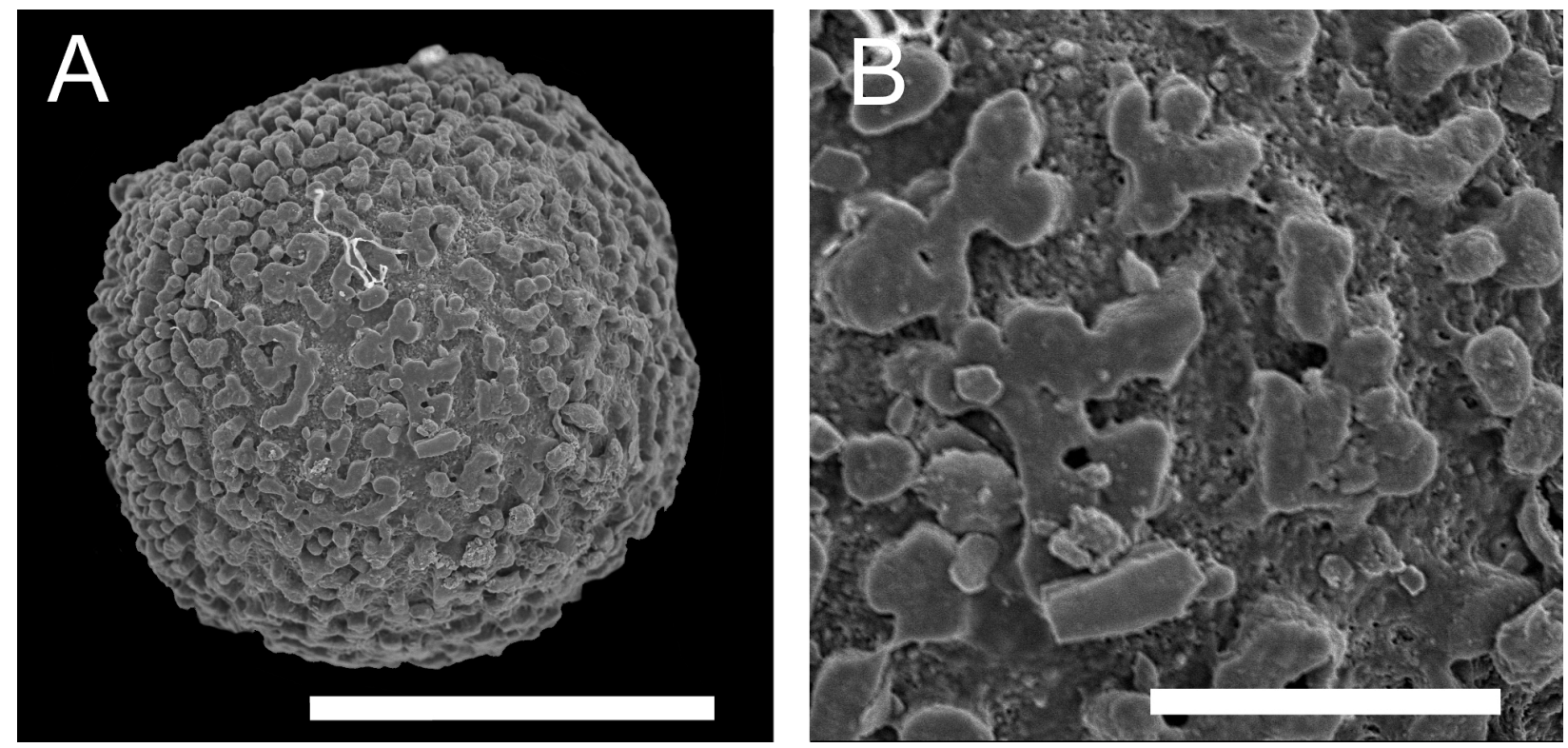

Fig. 3. SEM photographs of megaspores of Selaginella sanguinolenta: A - distal side of the spore; B - distal spore surface. Scale bar $200 \mu \mathrm{m}(\mathrm{A})$ and $50 \mu \mathrm{m}(\mathrm{B})$. 

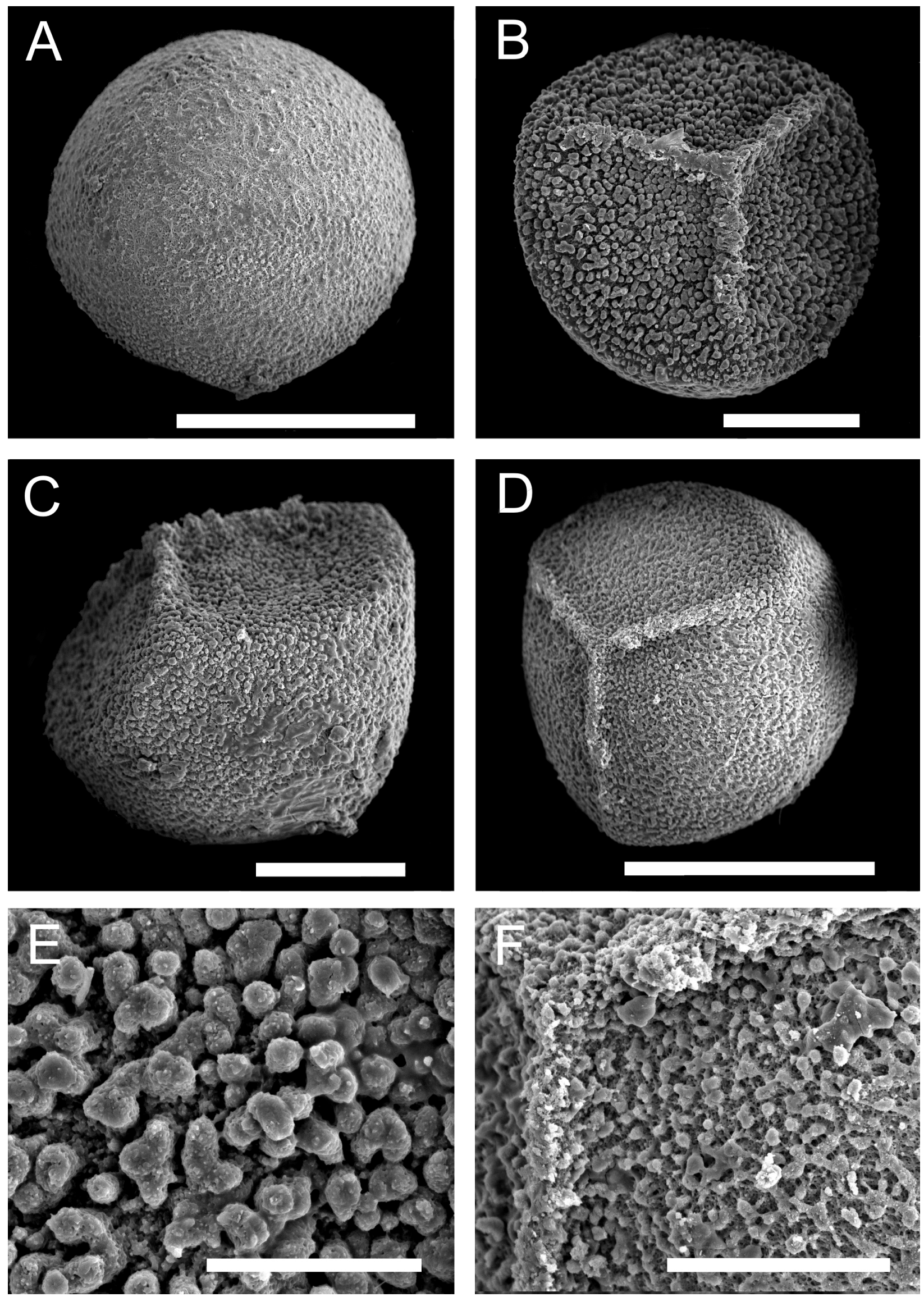

Fig. 4. SEM photographs of megaspores of Selaginella borealis: A - distal side of the spore; B - proximal side of the spore; $\mathrm{C}$ - the spore in equatorial position; $\mathrm{D}$ - the spore in equatorial-proximal position; $\mathrm{E}$ - distal spore surface; $\mathrm{F}$ proximal spore surface with a laesura. Scale bar $200 \mu \mathrm{m}$ (B, D), $100 \mu \mathrm{m}$ (A, C), $50 \mu \mathrm{m}$ (F) and 30 (E). 
(from 2.7 to 7.3 ) $\mu \mathrm{m}$ in diameter, reach 3.84 (from 2.6 to 5.3$) \mu \mathrm{m}$ in diameter near laesuras. The surface of exosporium is granular.

Specimen examined: "Tuvinskaya ASSR, PiyKhemskiy District, Uyukskiy Ridge, Borlug River valley, south slope, $\mathrm{H}=1400 \mathrm{~m}$. On the rocks. 17 VII 1976, No. 277. M. Lomonosova, A. Choodu. NS0004550" (NS).

The main distinctive feature of $S$. borealis and $S$. sanguinolenta based on the characteristics of the megaspore morphology is the nature of the exosporium surface. Representatives of $S$. borealis have the exosporium with rounded-polygonal tubercles of 3.8-4.9 $\mu \mathrm{m}$ in diameter, unlike the $S$. sanguinolenta exosporium covered with roller-like folds rising above sporoderm and reaching a width of 8.3 $\mu \mathrm{m}$. The $S$. borealis exosporium surface is granular and $S$. sanguinolenta one is rough. The form of the megaspore of $S$. borealis is rounded to tetrahedral, whereas $S$. sanguinolenta has the megaspore form only rounded. The size of the equatorial diameter differs in S. borealis and $S$. sanguinolenta slightly $296.2 \mu \mathrm{m}$ and $303 \mu \mathrm{m}$, respectively.

In a comparative analysis of the megaspore samples of our study with the samples presented in the work of Zhou et al. (2015a), images B, C and D of fig. 1 of $S$. sanguinolenta megaspores do belong to $S$. sanguinolenta, and picture A of fig. 1 - to $S$. borealis with characteristic tubercles on the exosporium surface and the tetrahedral form of megaspore peculiar only to it. Thus, our study has confirmed the presence of $S$. borealis in the territory of Yunnan (China).

We have also established that the SEM data and the description of the microspore morphology of representatives of $S$. sanguinolenta from the Khabarovsk Territory, the Republics of Buryatia, Tuva and the Irkutsk Region are identical to the microspore morphology of $S$. sanguinolenta from China (Yunnan). Species-specific features of microspores characterizing $S$. sanguinolenta are the presence of radially arranged convolutions on the proximal surface of the spore, outside the laesura, and convoluted folds on the distal surface of the microspore.

As a result of our study, the microspore morphology and images of $S$. helvetica representatives from the Chita Region, Trans-Baikal and Primorye Territories turned out to be identical to the morphology of the studied specimens from Liaoning province (China) in the work of Zhou and co-authors. Species-specific features of microspores characterizing S. helvetica are hemispherical distal side in the equatorial position and flat proximal side; the surface of the exosporium granular, completely covered with rounded-polygonal tubercles.

\section{Acknowledgments}

We are grateful to curators of the Herbariums of the CSBG SB RAS (NS, NSK), the Irkutsk State University (Herbarium named after V. I. Smirnov, IRKU), SIPPB SB RAS (IRK) and personally D. N. Shaulo, S. G. Kazanovsky and V. V. Chepinoga for the opportunity to work with collections and to select samples for the research. Special thanks to V. V. Kirillov and A. V. Dyachenko for their help in working with an electron scanning microscope in the laboratory of aquatic ecology of the Institute of Water and Environmental Problems of the Siberian Branch of the Russian Academy of Sciences.

The study was performed within the framework of the RFBR project (grant No. 18-54-53026 GFEN_a).

\section{REFERENCES / ЛИTEPATУPA}

Jermy A. C. 1990. Selaginellaceae. In: The families and genera of vascular plants, 1, Pteridophytes and gymnosperms. Eds. K. U. Kramer, P. S. Green. Springer, Berlin, Heidelberg, New York, 39-45 pp.

Korall P., Taylor W. A. 2006. Megaspore morphology in the Selaginellaceae in a phylogenetic context: A study of the megaspore surface and wall structure using scanning electron microscopy. Grana 45: 22-60. DOI: 10.1080/00173130500520453.

Tryon A. F., Lugardon B. 1991. The spores of pteridophytes: surface, wall structure, and diversity based on electron microscopy studies. Springer, Berlin, 648 pp.

Tzvelev N. N. 2004. About the genus Selaginella P. Beauv. s. 1. (Selaginellaceae) in Russia. Novosti sistematiki vysshikh rasteniy [Novit. Syst. Pl. Vasc.] 36: 22-27 [In Russian]. (Цвелев Н. Н. О роде Selaginella P. Beauv. s. 1. (Selaginellaceae) в России // Новости сист. высш. раст., 2004, Т. 36. С. 22-27).

Zhang X.-C., Kato M., Nooteboom H. P. 2013. Selaginellaceae. In: Flora of China. Vol. 2-3. Eds. Z. Y. Wu, P. H. Raven, D. Y. Hong. Science Press, Beijing; Missouri Botanical Garden Press, St. Louis, 37-66 pp.

Zhou X.-M., Jiang L.-J., Liang-Zhang, Gao X.-F., He Z.-R., Zhang L.-B. 2015a. Spore morphology of Selaginella (Selaginellaceae) from China and its systematic significance. Phytotaxa 237 (1): 1-67. DOI: 10.11646/phytotaxa.237.1.1. 
Zhou X.-M., Rothfels C. J., Zhang L., He Z.-R., Le Péchon, T., He H., Lu N. T., Knapp R., Lorence D., He X.-J., Gao X.-F., Zhang L.-B. 2015b. A large-scale phylogeny of the lycophyte genus Selaginella (Selaginellaceae: Lycopodiopsida) based on plastid and nuclear loci. Cladistics 32: 360-389. DOI: 10.1111/cla.12136.

Zhou X.-M., Zhang L.-B. 2015. A classification of Selaginella (Selaginellaceae) based on molecular (chloroplast and nuclear), macromorphological, and spore features. Taxon 64 (6): 1117-1140. DOI: 10.12705/646.2. 